\title{
Corporate Self-Investigations Under the Foreign Corrupt Practices Act
}

Corporations frequently conduct self-investigations to determine potential liability under the securities laws. The scope of privilege $^{1}$ to be accorded such investigations in a related private action is an area of controversy. For example, some courts have held that compliance with the disclosure requirements of the Securities Exchange Act of $1934^{2}$ constitutes a waiver of an otherwise available privilege. ${ }^{3}$ The Foreign Corrupt Practices Act of $1977^{4}$ ("FCPA") introduces further uncertainty into this area; this comment will explore the privileged status of corporate self-investigations made pursuant to that Act.

When a cause of action is statutorily based, one must examine the purpose and enforcement scheme of the legislation to determine whether a privileged status is appropriate. ${ }^{5}$ The FCPA con-

1 The law of evidence exempts "privileged" matter from disclosure. Rule 26 of the Federal Rules of Civil Procedure recognizes that privileged information is not subject to the otherwise broad scope of pretrial discovery. Wigmore has summarized four conditions for the establishment of a privilege of any kind:

(1) The communications must originate in a confidence that they will not be disclosed.

(2) This element of confidentiality must be essential to the full and satisfactory maintenance of the relation between the parties.

(3) The relation must be one which in the opinion of the community ought to be sedulously fostered.

(4) The injury that would inure to the relation by the disclosure of the communications must be greater than the benefit thereby gained for the correct disposal of the litigation.

$8 \mathrm{~J}$. Wigmore, Wigmore on Evidence § 2285, at 527 (rev. ed. 1961) (footnote omitted) (emphasis in original). The balancing expressed in the last condition should not be narrowly limited to the competing interests of plaintiff and defendant as they stand before the court. It should encompass as well the extent to which public policy is furthered by allowing some communications to remain confidential. See 4 J. Moore, Federal Practice II 26.22[2], at 1287 (2d ed. 1969) ("The public interest may be a reason for not permitting inquiry into particular matters by discovery").

215 U.S.C. $\$ \S 77 \mathrm{~b}-78 \mathrm{hh}(1976)$.

- See text and notes at notes 16-31 infra.

- Pub. L. No. 95-213, 91 Stat. 1494 (1977) (amending 15 U.S.C. $\$ \S 78 \mathrm{~m}(\mathrm{~b}), 78 \mathrm{dd}, 78 \mathrm{ff}(\mathrm{a})$ (1976)).

S See Webb v. Westinghouse Elec. Corp., 81 F.R.D. 431 (E.D. Pa. 1978) (holding that policy reasons for protecting an internal self-evaluation of compliance with federal employment discrimination laws must be balanced against plaintiff's need for such data because 
tains two sets of provisions. The first criminalizes the bribery of foreign politicians, ${ }^{,}$and the second creates a statutory requirement of accurate record keeping and accounting, applicable to all corporations subject to SEC regulation. ${ }^{7}$ Because the record keeping and accounting provisions are intended to enhance the reliability of required disclosure, the FCPA can be read to require corporate disclosure of any illegal payment. If this reading is in accord with congressional intent, one must question whether a corporate selfinvestigation undertaken to determine possible FCPA liability should be accorded any privilege.

This comment examines the legislative history of the FCPA and concludes that Congress did not intend to enact a "full disclosure" statute. Instead, the legislative intent was that high-level corporate management should be aware of illegal payments made by subordinates and should introduce internal controls to eliminate such illegality. The failure to do so results in significant criminal penalties for the individual officers or directors as well as for the corporate entity. The statute places a premium on corporate self-policing.

In many instances the record keeping and accounting requirements will not provide high-level management with the "awareness" the statute mandates; a self-investigation will be essential. The congressional goal of self-policing will not be realized, however, if the corporation undertaking such an investigation fears compelled disclosure of its self-evaluation in a suit by shareholders or competitors. ${ }^{8}$ The comment concludes that such investigations

discrimination laws rely partially on private actions for enforcement).

- Foreign Corrupt Practices Act of 1977, Pub. L. No. 95-213, § 103, 91 Stat. 1494 (1977) (amending 15 U.S.C. § 78dd (1976)).

I Id. § 102 (amending 15 U.S.C. § 78q(b) (1976)).

s The statute does not clearly provide a private right of action and the legislative history is ambiguous. The House Committee Report endorsed the private right of action, H.R. REP. No. 640, 95th Cong., 1st Sess. 10 (1977), but considered only the bribery provisions of the FCPA. On the other hand, the Senate Committee, which considered the books and accounting provision as well, rejected the private right of action. S. REP. No. 1031, 94th Cong., $2 d$ Sess. 12 (1976). The reason for this rejection, however, was that the Committee believed the proposal "would have duplicated and possibly confused existing remedies available to shareholders." Id. at 12-13. The SEC has taken a strong position that a private right of action should be implied on behalf of persons who suffer injury as a result of prohibited bribery. Opinion Letter, [1978 Transfer Binder] FED. SEc. L. REP. (CCH) I 81,701 (1978). If such a right of action were recognized, it would extend in favor of competitors and shareholders, the two groups intended to benefit from the FCPA. See Program, Foreign Corrupt Practices Act of 1977 and the Regulation of Questionable Payments, 34 Bus. LAw. 623, 64041 (1979). 
must be privileged if the purposes of the FCPA are to be met.

Finally, the comment addresses the question whether such an investigation can be shielded by either the attorney-client privilege ${ }^{9}$ or the self-evaluative privilege. ${ }^{10}$ The attorney-client privilege is effective in this situation only if the broad "subject matter" test

- The attorney-client privilege represents one situation in which the balancing of interests between disclosure and confidentiality has weighed in favor of confidentiality. The modern justification for the attorney-client privilege is that it is "necessary "in the interest and administration of justice" "for a client to consult freely with his attorney. United States v. United Shoe Mach. Corp., 89 F. Supp. 357, 358 (D. Mass. 1950) (quoting Hunt v. Blackburn, 128 U.S. 464 (1888)).

Wigmore describes the situation in which the attorney-client privilege is applicable: "(1) Where legal advice of any kind is sought (2) from a professional legal adviser in his capacity as such, (3) the communications relating to that purpose, (4) made in confidence (5) by the client, (6) are at his instance permanently protected (7) from disclosure by himself or by the adviser, (8) except the protection be waived." $8 \mathrm{~J}$. WIGMORE, supra note $1, \S 2292$, at 554 (emphasis omitted) (footnote omitted). When these criteria are met, a court need not consider the competing demands of disclosure and confidentiality in their particular factual or statutory context because the preservation of attorney-client confidentiality is paramount.

Courts have abrogated the attorney-client privilege, however, when there have been sufficient competing policy considerations. In Garner v. Wolfinbarger, 280 F. Supp. 1018 (N.D. Ala. 1968), the district court held that the corporate attorney-client privilege should never be available against stockholder plaintiffs. The Fifth Circuit, on appeal, rejected such a black letter law and placed on plaintiffs the burden of showing "good cause" why discovery should be allowed. Garner v. Wolfinbarger, 430 F.2d 1093, 1104 (5th Cir. 1970), cert. denied, 401 U.S. 974 (1971). Despite cogent objections by commentators, see Brerton, Abrogation of the Corporate Privilege in Stockholder Suits, PrAc. LAw., Nov. 1969, at 24, 26; Comment, The Attorney-Client Privilege in Shareholders' Suits, 69 Colum. L. REv. 309, 318 (1969), courts uniformly have adopted the Garner reasoning, extending it to a situation in which a fiduciary owed a duty to two different corporations involved in litigation, e.g., Bailey v. Meister Brau, Inc., 55 F.R.D. 211 (N.D. IIl. 1972), and to the fiduciary duty of a parent corporation to its subsidiary, e.g., Valente v. Pepsi Co., 69 F.R.D. 361 (D. Del. 1975). Valente, in fact, went so far as to shift the burden to the defendant to show why discovery should not be allowed. Courts in subsequent cases have followed the Garner allocation of the burden. E.g., Panter v. Marshall Field \& Co., 80 F.R.D. 718 (N.D. Ill. 1978); In re Transocean Tender Offer Sec. Litigation, 78 F.R.D. 692 (N.D. Ill. 1978); Cohen v. Uniroyal, Inc., [1978 Transfer Binder] Fed. Sec. L. Rep. (CCH) I 96,868 (E.D. Pa. 1978).

When it is not clear to the court, however, that the attorney-client relationship demands protection of certain communications, the court must look to the underlying purposes of privilege to determine whether the balance nevertheless weighs in favor of protection from disclosure. The applicability of the attorney-client privilege therefore may be a starting point in a court's analysis, but its resolution should not be dispositive of whether "privilege" is essential to further public policy.

10 The self-evaluative privilege protects the subjective aspects of certain self-investigations from disclosure. Courts have explicitly recognized public policy as a justification for this privilege. See, e.g., Bredice v. Doctors Hosp., Inc., 50 F.R.D. 249 (D.D.C. 1970), aff'd, 479 F.2d 920 (D.C. Cir. 1973) (monthly review report prepared by hospital's medical staff held not discoverable in a medical malpractice case; privilege justified by the public interest in the continued preparation of such self-evaluative reports which might cease if not shielded from discovery). See text and notes at notes 70-79 infra. 
rather than the "control group" test is applied." The self-evaluative privilege, as it is currently applied by the courts, would protect the self-investigation from discovery only in a minority of cases. The comment therefore concludes that courts must either apply the subject-matter test of attorney-client privilege or broaden the formulation of the self-evaluative privilege. ${ }^{12}$ In either case, the concept of waiver should not be relied on to abrogate the necessary privilege.

\section{Privilege and Disclosure Under the Securities Exchange Act of 1934 Prior to ENACtMent of the FCPA}

It is the obligation of the SEC to ensure that investors are fully informed of material financial dealings of subject corporations. ${ }^{13}$ It is therefore not surprising that the Commission viewed increasing evidence of foreign bribery as a frustration of the system of corporate accountability "on which the securities laws-and indeed our system of mass capital formation-rest."14 The response of the Commission to such payments, prior to enactment of the FCPA, was designed to eliminate concealment. Two approaches have been used: (1) vigorous enforcement of existing securities laws prohibiting concealment of material information, coupled with investigations by disinterested outside counsel (the

11 Courts are in disagreement regarding the appropriate formulation of the attorneyclient privilege when the client is a corporation. Two major tests prevail. The majority of jurisdictions apply the "control group" test fashioned by Judge Kirkpatrick in City of Philadelphia v. Westinghouse Elec. Corp., 210 F. Supp. 483 (E.D. Pa. 1962), mandamus and prohibition denied sub. nom. General Elec. Co. v. Kirkpatrick, 312 F.2d 742 (3d Cir. 1962), cert. denied, 372 U.S. 943 (1963). See text and notes at notes 66-67 infra. Other jurisdictions apply variations of the "subject matter" test first applied in Harper \& Row Publishers, Inc. v. Decker, 423 F.2d 487 (7th Cir. 1970), aff'd by an equally divided court, 400 U.S. 348 (1971). See text and notes at notes 61-66 infra. The Supreme Court recently has granted certiorari to resolve this dispute in United States v. Upjohn Co., 600 F.2d 1223 (6th Cir. 1979), cert. granted, $100 \mathrm{~S}$. Ct. 1310 (1980). See text and notes at notes 61-69 infra.

12 This comment does not consider the protection offered by the work-product doctrine. The doctrine is limited to work "in anticipation of litigation," FED. R. CIv. P. 26(b)(3). A corporation subject to the FCPA would normally want, and would be encouraged by the self-policing scheme of the statute, to conduct such an investigation at the first suspicion of wrongdoing, rather than only in anticipation of a specific lawsuit.

13 "The securities laws are designed primarily to ensure disclosure to investors of all the relevant facts concerning corporations which seek to raise their capital from the public at large." Foreign Corrupt Practices and Domestic and Foreign Investment Disclosure: Hearings on S. 305 Before the Comm. on Banking, Housing \& Urban Affairs, 95th Cong., 1st. Sess. 125 (1977) (statement of Roderick M. Hills, then chairman of the SEC) [hereinafter cited as Hearings on S. 305].

${ }^{14}$ Id. at 121 (statement of Roderick M. Hills). 
special counsel program); and (2) a disclosure program in which "[c]ompanies which believe that some type of a payment problem has not been properly disclosed to investors may come to the Commission's staff, discuss the situation, conduct an internal investigation, and make appropriate disclosure in Commission filings"15 (the voluntary disclosure program).

The interest of the Commission in providing full disclosure to investors does not determine whether internal investigations conducted by special counsel or pursuant to the voluntary disclosure program should be discoverable in a subsequent private action. No court has discussed whether such investigations should be privileged solely as a matter of public policy. Instead, judicial attention has been focused on the attorney-client relationship as the basis for privilege.

In cases in which the attorney-client privilege has been found applicable, courts have disagreed as to whether disclosure to the SEC constituted a "waiver" of the privilege. ${ }^{16}$ The result of applying the waiver doctrine is that the investigation is not privileged. The same result would have been reached had the courts concluded that the disclosure policy of the securities laws outweighed the interest in confidentiality, ${ }^{17}$ and held the attorney-client privilege inapplicable in these cases. No court has so held.

The self-regulation mandated by the FCPA is more likely to require periodic corporate self-investigation than either the special counsel or voluntary disclosure programs. Thus, description of the courts' approach to privilege under these earlier programs is an important starting point for an analysis of privilege under the FCPA.

1s Id. at 118 (statement of Roderick M. Hills).

16 The concept of waiver implies that the client (for whose benefit the attorney-client privilege exists) voluntarily relinquishes the confidentiality of the communication. $8 \mathrm{~J}$. WIGMORE, supra note $1, \S 2327$, at 634 . The rationale behind waiver is that it is unfair for one party to disclose only those facts beneficial to its case while cloaking other facts in secrecy. Hercules, Inc. v. Exxon Corp., 434 F. Supp. 136, 156 (D. Del. 1979); Handgards, Inc. v. Johnson \& Johnson, 413 F. Supp. 926, 929 (N.D. Cal. 1976); 8 J. WigmoRE, supra note 1, $\S 2327$, at 634-36. This reasoning is not applicable to the situation in which disclosure is made to a regulatory agency such as the SEC. Although disclosure pursuant to the voluntary disclosure program often results in more lenient treatment by the SEC, the program's principal function is as a deterrent mechanism. Hearings on S. 305, supra note 13, at 118 (statement of Roderick M. Hills). Corporate disclosure in this instance is better characterized as compelled by regulatory obligations than as "voluntary."

${ }^{17}$ This balancing is a necessary requirement for any privilege to attach. See $8 \mathrm{~J}$. WIGMORE, supra note $1, \S 2285$, at 527. 


\section{A. Voluntary Disclosure Program Cases}

In Diversified Industries, Inc. v. Meredith, ${ }^{18}$ the corporation had surrendered to the SEC documents that it claimed were privileged in the subsequent private antitrust litigation. The Eighth Circuit found only a "limited" waiver, citing a policy argument to buttress a broad application of the privilege: that the interest in encouraging corporations to investigate and correct internal wrongdoing outweighed the interest in allowing the plaintiffs broad discovery. ${ }^{19}$

Two later cases, ${ }^{20}$ however, have found a total waiver of the privilege. For example, in United States $v$. Upjohn Co. ${ }^{21}$ a district court found a waiver of all underlying data pertinent to illegal foreign payments, as the result of merely filing required reports with the SEC. ${ }^{22}$ Following notification of possible illegality by outside auditors, the defendant's general counsel conducted a factual investigation. He and outside counsel mailed a written questionnaire to managers of foreign affiliates. They subsequently conducted telephone interviews with these managers, and the general counsel made notes of these interviews. The corporation filed preliminary and amended reports with the SEC, sending copies of both to the

1s 572 F.2d 596, 606 (8th Cir. 1978) (en banc).

19 Id. at 611 (en banc). The court did not define its use of the term "limited waiver." Its reasoning, and the authorities it cites, Bocks County Bank \& Trust Co. v. Storck, 297 F. Supp. 1122 (D. Hawaii 1969); United States v. Goodman, 289 F.2d 256, 259 (4th Cir.), vacated on other grounds, 368 U.S. 14 (1969), indicate that the confidential material submitted to the SEC retained its privileged status in the subsequent private litigation. This result is in sharp contrast to the holdings of those courts that have found a partial disclosure to constitute a waiver of all underlying data related to the same subject matter, United States v. Cote, 456 F.2d 142, 144-45 (8th Cir. 1972); IBM v. Sperry Rand Corp., 44 F.R.D. 10, 13 (1968).

30 Both cases found the attorney-client privilege inapplicable but went on to hold that, in any event, the privilege would have been waived by the disclosure to the SEC. United States v. Upjohn Co., 78-1 U.S. Tax Cas. 84,152 (W.D. Mich.) (adopting Report and Recommendation of Magistrate, 78-1 U.S. Tax Cas. 83,597, 83,603 (W.D. Mich.)), aff'd in part, rev'd in part and remanded, 600 F.2d 1223 (6th Cir. 1978), cert. granted, 100 S. Ct. 1310 (1980); SEC v. Dresser Indus., Inc., 453 F. Supp. 573, 576 (D.D.C. 1978). It is important to note that both cases concerned discovery efforts by regulatory agencies rather than by private litigants. The reluctance of courts to inhibit the agency's regulatory duties by imposition of the privilege is understandable. The broad waiver holdings, however, would permit discovery by subsequent private litigants as well.

21 78-1 U.S. Tax Cas. 84,152 (W.D. Mich.) (adopting Report and Recommendation of Magistrate, 78-1 U.S. Tax Cas. 83,597 (W.D. Mich.)), aff'd in part, rev'd in part and remanded, 600 F.2d 1223 (6th Cir. 1978), cert. granted, 100 S. Ct. 1310 (1980).

22 78-1 U.S. Tax Cas. at 83,603 (Magistrate's Report and Recommendation, adopted by district court, 78-1 U.S. Tax Cas. 84,152 (W.D. Mich. 1978)). 
IRS. After determining that approximately half of the illicit payments did not affect its tax liability, the corporation permitted the IRS to interview its employees, but prohibited questions relating to the payments it deemed irrelevant to the tax liability.

After applying the control group test, ${ }^{23}$ the court held that by voluntarily disclosing data relating to the payments, Upjohn had waived any privilege regarding that matter, if such a privilege had existed. ${ }^{24}$ Had a private suit followed, the plaintiffs might have argued that Upjohn's disclosure of all the underlying data to the IRS waived any claim to privilege.

In contrast, the Southern District of New York recently held in Byrnes v. IDS Realty Trust ${ }^{25}$ that disclosure pursuant to the voluntary disclosure program did not constitute a waiver of the attorney-client privilege. Stating that a refusal to extend the waiver beyond the agency to which the disclosure had been made "may be inappropriate where unfairness would result to the party attacking the privilege," the case before it had "not established how the disclosure to the SEC prejudiced them." The court then went on to say that "[ $t]$ he only prejudice that appears to arise results whenever a party is deprived of information it would rather have. Such prejudice is neither caused nor exacerbated by the disclosure of privileged in-

2s See note 11 supra.

24 The Sixth Circuit indicated that the corporation's "voluntary" disclosures to the SEC amounted to a waiver of the privilege only with respect to those facts actually disclosed to the SEC. 600 F.2d at 1227 n.12. The authority cited for this proposition, however, includes the same case relied on by the district court in its holding of a total waiver, U.S. v. Cote, 456 F.2d 142 (8th Cir. 1972). The Sixth Circuit also cited IBM v. Sperry Rand Corp., 44 F.R.D. 10 (1968), which held that a partial disclosure waived the privilege as to all underlying data related to the subject matter of the disclosures, $i d$. at 144-45. The holding of the court of appeals as to waiver therefore is ambiguous. Although the Sixth Circuit clearly did not follow the Diversified court in limiting waiver to the SEC, see text and note at note 19 supra, it is unclear to what extent a plaintiff in subsequent private litigation arising from the illegal payments made by Upjohn could discover the fruits of the corporation's internal investigation.

A second problem in the Sixth Circuit's handling of the waiver question is that it concluded that the disclosures to the SEC were voluntary. The court indicated they were voluntary because they were made "in the hope of lenient treatment by the SEC." 600 F.2d at 1225. The voluntary disclosure program, however, was a primary means of deterring illegal foreign payments prior to enactment of the FCPA. Disclosures made pursuant to the program are not "voluntary" in the sense that is normally associated with waiver. See note 16 supra.

${ }^{23} 85$ F.R.D. 679 (S.D.N.Y. 1980).

2s Id. at 688 .

${ }^{27}$ Id. at 689 . 
formation to the SEC in a separate, nonpublic proceeding to which the plaintiffs were not a party."28

\section{B. Special Counsel Cases}

A curtailment of the attorney-client privilege in special counsel cases could be explained on either of two grounds: that the corporation did not seek legal advice from the special counsel because he functioned as an investigator serving the public interest, ${ }^{29}$ or that the corporation already had evidenced an unwillingness to cooperate with the SEC and, therefore, the interest in disclosure outweighed any interest in confidentiality.

In SEC $v$. Boeing Co., ${ }^{30}$ however, the court held that limited disclosure to the SEC would not constitute a general waiver of the attorney-client privilege. It gave access to privileged Boeing documents only to a special committee formed pursuant to a Consent and Undertaking Agreement and precluded the SEC from obtaining such materials unless a court order was issued to the effect that turning over the documents did not constitute a waiver. Boeing is consistent with an earlier decision in the same district, SEC v. Lockheed Aircraft Corp. ${ }^{31}$ which held that furnishing privileged documents to special counsel did not constitute a waiver and that the SEC could obtain the documents only if a separate court order declared that such action did not waive the privilege.

\section{Summary}

Prior to enactment of the FCPA, no court explicitly held that internal investigations into possibly illegal payments should be disclosed as a matter of policy; similarly, no court premised a finding of "privilege" on a weighing of policy interests. Instead, courts relied on the attorney-client privilege and the concept of waiver to resolve the issue.

Waiver, however, requires a voluntary disclosure of otherwise privileged information. Thus, the courts that have found a "waiver" when corporations divulged information to special counsel pursuant to court order or conducted an internal investigation in compliance with the voluntary disclosure program have ignored

${ }^{28}$ Id.

29 The court in SEC v. Canadien Javelin, [1978 Transfer Binder] FED. SEC. L. REP. (CCH) I 96,441 (D.D.C. 1978), followed such a line of reasoning.

so Civ. No. 78-1383 (D.D.C. July 28, 1978).

s1 Civ. No. 75-0611 (D.D.C. Apr. 13, 1976). 
the fact that such actions were required by the SEC as an integral part of its enforcement of the securities laws. Such disclosures cannot realistically be deemed "voluntary."

Those jurisdictions that have applied the broader subjectmatter test ${ }^{32}$ of corporate attorney-client privilege have found such internal investigations protected from discovery. Others have applied the restrictive control-group test, ${ }^{3 s}$ and denied the privilege. Although no court applying the broader test also found the privilege waived by partial disclosure to the SEC, the threat of such a result was anticipated by those courts that specifically said that future cooperation with the SEC would not constitute a waiver. ${ }^{34}$

\section{The Intent of the FCPA and Its Effect on Privilege Claims}

The provisions of the FCPA point in two directions: criminalization of bribery of foreign political officials ${ }^{35}$ and enhanced reliability of disclosure. ${ }^{38}$ The criminal sanctions are applicable even if a corporation makes full disclosure to the SEC. Violation of the section 102 disclosure provisions is a separate offense. ${ }^{37}$ Read together, the two sets of provisions lead to two differing interpretations of congressional intent.

The first possible conclusion is that Congress intended to enact a "full disclosure" statute requiring corporations to make public any evidence of illegal foreign payments. If this were the congressional purpose, a strong argument could be made that shareholders and competitors, as the beneficiaries of the legisla-

32 See, e.g., Diversified Indus., Inc. v. Meredith, 572 F.2d 596, 606 (8th Cir. 1977) (en banc); Byrnes v. IDS Realty Trust, 85 F.R.D. 679 (S.D.N.Y. 1980); In Re Grand Jury Subpoena, 478 F. Supp. 368 (E.D. Wis. 1979).

ss See, e.g., United States v. Upjohn Co., 78-1 U.S. Tax Cas. 84,152 (W.D. Mich.) (adopting Report and Recommendation of Magistrate, 78-1 U.S. Tax. Cas. 83,597 (W.D. Mich.)), aff'd in relevant part, 600 F.2d 1223 (6th Cir. 1978), cert. granted, 100 S. Ct. 1310 (1980).

s4 See, e.g., SEC v. Boeing Co., Civ. No. 78-1383 (D.D.C. July 28, 1978); SEC v. Lockheed Aircraft Corp., Civ. No. 75-0611 (D.D.C. Apr. 13, 1976).

ss Pub. L. No. 95-213, § 103, 91 Stat. 1495 (1977) (amending 15 U.S.C. § 78dd (1976)).

${ }^{36}$ Id. § 102, 91 Stat. 1494 (amending 15 U.S.C. § 78m (1976)).

${ }^{37}$ Kenneth J. Bialkin, Chairman of the Federal Regulation of Securities Committee of the American Bar Association, stated:

It would be very difficult . . . for any lawyer to suggest that, where such a violation [of sections 103 or 104] exists, one should not also have a duty to disclose it. So that you might really find yourself with a double problem. One, the substantive violation; and two, the failure to make a disclosure of the fact that you have committed that violation. Program, supra note 8 , at 643. 
tion, should have access to all underlying data in pursuing a private cause of action. In this case, the public interest in disclosure would overcome the interest in confidentiality because "disclosure" is a vital aspect of the enforcement scheme. No privilege should be accorded an internal investigation under this interpretation. ${ }^{38}$

The second possible reading of the FCPA is that Congress intended to deter foreign bribery by enhanced corporate self-policing. Section 102 is material not so much in changing the disclosure obligation of the corporation to the $\mathrm{SEC}^{39}$ or as an independent enforcement scheme, but in ensuring that top-level management will become aware of any illicit payments made by subordinates on behalf of the corporation. These corporate officials have a duty to deter such activity. Their failure to do so results in significant criminal sanctions for them as individuals as well as for the corporate entity. The most effective self-policing, however, often will require an internal investigation, not only to detect bribery, but to make certain that corporate record keeping will keep top-level management fully informed. If this is the purpose of the legislation, internal corporate investigations are paramount in the deterrent scheme envisioned by Congress and public policy requires their protection from discovery.

The legislative history of the FCPA demonstrates that a strong minority of congressmen and executive officials felt that full disclosure would be the most effective deterrent of foreign bribery. Undoubtedly, they would support the first interpretation of the statute outlined above. The majority, however, rejected a full disclosure policy and enacted legislation that relies heavily on corporate self-policing as a deterrent.

\section{A. Disclosure Requirements of the FCPA}

Disclosure obligations were a major focus of Congress as it shaped the FCPA. Earlier Senate bills addressing the issue of foreign bribery required full corporate disclosure of payments to foreign officials and political parties, including those that might not meet the narrow definition of a bribe but were at least of questionable propriety..$^{40}$ This approach was rejected, however, in legisla-

ss See 8 J. WigmoRE, supra note $1, \S 2285$, at 527 .

30 See text and note at note 46 infra.

40 See S. REp. No. 1031, 94th Cong., 2d Sess. 9 (1976). Such disclosure was required under previous Senate bills, S. 3313 and S. 3379, and possibly under the proposals of the Task Force on Questionable Corporate Payments Abroad ("Richardson Task Force"). The 
tion that passed the Senate in $1976 .^{41}$ The Senate Committee concluded that criminalization would provide a stronger policy statement and that a full disclosure statute would be as difficult for the government to enforce, ${ }^{42}$ if not more so. ${ }^{43}$

The Senate bill passed in 1976, which was identical to the bill reintroduced in 1977 that eventually became the FCPA,4 did, however, require the establishment and maintenance of internal record keeping and accounting controls. ${ }^{45}$ The Committee on Banking, Housing and Urban Affairs, which conducted hearings on the bill, believed that such requirements were implicit in the existing securities laws. ${ }^{46}$ They were made explicit, however, for two

proposal of the Task Force was not in legislative form at the time the Senate Committee on Banking, Housing and Urban Affairs considered S. 3664. The Task Force recommended disclosure by all domestic concerns of payments in excess of some floor amount made in connection with the obtaining or maintenance of business with a foreign government. See $\mathrm{S}$. Rep. No. 1031, 94th Cong., 2d Sess. 2 (1976).

43 S. 3664 rejected the "full disclosure" approach. This bill was passed by the Senate by a vote of 86-0 on September 15, 1976. 122 Cong. REc. 30426 (1976). The House, however, did not complete its consideration of the legislation prior to adjournment. The bill was reintroduced in the Senate in 1977 as S. 305 which, after amendment by the House, was enacted as the FCPA. S. REP. No. 114, 95th Cong., 1st Sess. 2 (1977), reprinted in [1977] U.S. CoDE Cong. \& AD. NEws 4098, 4099.

${ }^{12}$ S. Rep. No. 1031, 94th Cong., 2d Sess. 8 (1976). The report noted that whether a "full disclosure" or "criminalization" approach was chosen, the government would have to prove both that the undisclosed payment was made and that it was made with an improper purpose. If a "full disclosure" statute were enacted, it would further require proof that the issuer willfully failed to file a report. Id.

is S. Rep. No. 114, 95th Cong., Ist Sess. 10 (1977), reprinted in [1977] U.S. CodE Cong. \& AD. News 4098, 4107.

4 See note 41 supra.

16 Pub. L. No. 95-213, § 102, 91 Stat. 1494 (1977) (amending 15 U.S.C. $\S 78 \mathrm{~m}(\mathrm{~b})$ (1976)). S. 305 originally contained an additional provision, $\S 102(\mathrm{~b})(4)$, which was deleted because of objection by the House. 123 Cong. Rec. H12,723 (daily ed. Dec. 6, 1977). This provision explicitly prohibited knowingly making false or misleading statements, or knowingly omitting to state facts necessary to be stated, to an accountant in connection with any audit or examination of issuers identified in $\S 13(\mathrm{~b})(2)$ of the Securities Exchange Act of 1934, 15 U.S.C. $\$ 78 \mathrm{~m}(2)$ (1976). The provision was deleted because Congress did not want to become embroiled in the controversy over the term "knowingly" as applied in the securities laws. H.R. Conp. REP. No. 831, 95th Cong., 1st Sess. 10-11 (1977), reprinted in [1977] U.S. Code Cong. \& AD. News 4121, 4123.

16 S. RkP. No. 1031, 94th Cong., 2d Sess. 11 (1976). Despite this belief of the Committee, the accounting profession is uncertain whether section 102 requires a standard of disclosure different from the "materiality" standard embodied in preexisting securities laws. Prior to the FCPA, disclosure to the SEC was necessary only when a material discrepancy existed. Materiality could exist in a quantitative sense or a qualitative one, in that it "reflect[ed] adversely on integrity of management or reliability of the books and records." J. West, White Collar Crime: An Accountant's Perspective 58 (address to Securities Regulation Institute, San Diego, Cal., Jan. 17, 1979). Although section 102 speaks of "reasonable detail" and "reasonable assurances," it does not use the term "material." Apparently, management and 
reasons: the fundamental nature of management's stewardship responsibility to shareholders, ${ }^{47}$ and the belief that "in the past, corporate bribery had been concealed by the falsification of corporate books and records." 48 The Committee went on to state that "Title I removes this avenue of coverup, reinforcing the criminal sanctions which are intended to serve as the significant deterrent to corporate bribery. Taken together, the accounting requirements and criminal prohibitions of Title I should effectively deter corporate bribery of foreign government officials." 49

The Senate bill therefore provided that criminal sanctions should be the principal deterrent of foreign bribery. It reinforced its purpose by expressly addressing what was viewed as the major source of abuse under preexisting law, namely, falsification of and omissions from corporate books and records. The Senate rejected, at least for the time being, strong encouragement from both Secretary of the Treasury Blumenthal ${ }^{30}$ and former Secretary of Commerce Richardson ${ }^{51}$ to enact a "disclosure" statute.

The House of Representatives was even less disposed to enactment of a full disclosure statute. It first reacted to S. 305 by substituting its own bill ${ }^{52}$ which omitted any reference to accounting or record-keeping standards. Eventually, however, the House acceded to the Senate on the inclusion of section 102, insisting only on minor changes in wording. ${ }^{\text {ss }}$ Thus, the legislative history of the FCPA

its accountants must determine whether "reasonable" is the equivalent of "material" or whether it creates a new standard.

17 S. REP. No. 114, 95th Cong., 1st Sess. 8 (1977), reprinted in [1977] U.S. Code Cong. \& AD. NEws 4098, 4105.

48 Id. at 3, reprinted in [1977] U.S. Code Cong. \& Ad. News 4098, 4100.

4 Id.

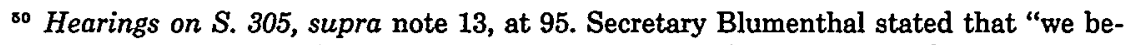
lieve that disclosure should be another route that is pursued vigorously, and perhaps some further analysis might be done as to how our disclosure requirements might be strengthened."

${ }^{51}$ The Minority Views to H.R. 3815 quoted the report of the Richardson Task Force: "The Task Force has concluded . . . that the criminalization approach would represent little more than a policy assertion, for the enforcement of such a law would be very difficult if not impossible." H.R. REP. No. 640, 94th Cong., Ist Sess. 20 (1977) (Minority Views). The minority went on to say that "on the other hand, disclosure could be a very effective deterrent especially in combination with the other sanctions against such payments which exist in present securities, antitrust, tax and criminal law." Id.

${ }^{32}$ The House struck out everything after the enacting clause ( $\left.\$ 101\right)$ of S. 305 and substituted H.R. 3815 which had nothing analogous to section 102 (the accounting and record-keeping provisions) of S. 305.123 CoNG. Rec. H11,936 (daily ed. Nov. 1, 1977).

ss The House acceded to the Senate on the section 102 provisions but substituted "in reasonable detail" for the "accurate and fair" requirement in S. 305. H.R. CoNr. REP. No. 
is clear in rejecting a full disclosure approach to the regulation of bribery of foreign politicians.

\section{B. Corporate Self-Policing Under the FCPA}

Both the language of the statute and its legislative history support the conclusion that Congress intended corporate officials to be aware of, and to take responsibility for, the acts of their subordinates. Section 102 requires that the system of internal accounting controls provide "reasonable assurances that . . . transactions are executed in accordance with management's general or specific authorization." U.S. company which 'looks the other way' in order to be able to raise the defense that they were ignorant of bribes made by a foreign subsidiary, could be in violation of section 102."

The statute proscribes only corporate bribery; it is not intended to reach activity by an employee acting on his own. The determination whether bribery is a "corporate" or "individual" act may well depend on the corporation's willingness to police itself, indicated by such factors as "the care with which the board of directors supervises management, the care with which management supervises employees in sensitive positions and its adherence to the strict accounting standards set forth under section 102." ${ }^{168} \mathrm{Har}-$ vey L. Pitt, General Counsel of the SEC, has also indicated that the corporation that diligently assumes the responsibility of selfpolicing may be immune from liability under the FCPA. ${ }^{.7}$

831, 95th Cong., 1st Sess. 10 (1977), reprinted in [1977] U.S. Code Cong. \& AD. NEws 4098, 4122. The more substantive change insisted on by the House was the deletion of section 102(b)(4). See note 45 supra.

s6 Pub. L. No. 95-213, § 102, 91 Stat. 1494 (1977) (amending 15 U.S.C. § 78m(b) (1976)) (emphasis added).

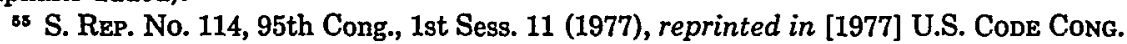
\& AD. News 4098,4109 . Rules recently proposed by the SEC would place on management the duty to certify the adequacy of the corporation's internal accounting controls. Statement of Management on Internal Accounting Control: SEC Rule Proposals, [Jan.-June 1979] Sec. Reg. \& L. Rep. (BNA) No. 501 (Supp.) at 3 (1979). For periods ending after December 15, 1980, "the statement by management on internal accounting [would] be examined and reported on by an independent public accountant." Id. at 4.

se S. REP. No. 114, 95th Cong., 1st Sess. 11 (1977), reprinted in [1977] U.S. Code Cong. \& AD. News 4098, 4108.

${ }^{87}$ [I]f a corporation has established standards of conduct (it should be able to point to those, namely directives to its employees), and established a means of reviewing the effectiveness of those standards (spot checks, occasional seminars with employees, directives from top personnel of the management of the corporation, and the like), and the corporation reviews specific areas where the possibility of violations of the Act are 
The willingness to conduct an internal self-investigation before litigation is imminent (in which case it might well be protected by work-product immunity) is directly in keeping with the intent to encourage self-policing that underlies the FCPA. Yet such willingness will be severely reduced, if not eliminated, if the fruits of the corporation's labor can be turned against it by a plaintiff in subsequent private litigation.

\section{Summary: Privilege v. Disclosure}

The criminalization and record-keeping sections of the FCPA provide a consistent system of deterrence only if they are read together to require top-level management to become aware of any illicit foreign payments. The statute therefore states a strong policy of self-policing. That policy is more likely to require periodic corporate self-investigation than either the special counsel or voluntary disclosure programs utilized by the SEC to deter corporate bribery prior to enactment of the FCPA. If such self-investigations are to become realities, corporations cannot be vulnerable to having their investigatory results used against them in subsequent private litigation. Such a dilemma would do more to deter corporate self-policing than it would corporate bribery. "Privilege" is appropriate whenever, as here, the societal benefits of confidentiality outweigh the benefits of disclosure.

\section{Attorney-Client and Self-Investigative Privileges}

Under the existing laws of privilege, two possible protections are available to corporations: the attorney-client privilege or the self-investigative privilege. As they currently are construed, neither privilege is consistently available to a corporation conducting an internal investigation. Courts must eliminate such unpredictability if corporations are to engage diligently in self-policing.

The limitations in each privilege, as currently applied, are explored below. This comment concludes that either the subject-matter test-rather than the control-group test-must be adopted as the standard for attorney-client privilege, or the self-investigative privilege must be read more broadly to include FCPA selfinvestigations.

rampant, I think a good faith defense has been established.

Program, supra note 8, at 642 (emphasis added). 


\section{A. Corporate Attorney-Client Privilege}

When a client seeks legal advice from an attorney, all communications that are made in confidence and that relate to the subject on which advice is sought are permanently protected from discovery unless the protection is waived..$^{88}$ To the extent that a self-investigation conducted by either in-house or outside counsel gives rise to an attorney-client relationship, the attorney-client privilege can provide a permanent shield to disclosures made by the client. The scope of the privilege when the client is a corporation, however, is still an area of major controversy. ${ }^{69}$ The principal issue

ss $8 \mathrm{~J}$. Wigmore, supra note $1, \S 2292$ at 554.

so See note 9 supra. See also Note, Attorney-Client Privilege for Corporate Clients: The Control Group Test, 84 HaRv. L. REv. 424 (1970) (endorsing the control-group test). But see commentary critical of the control-group test: Burnham, The Attorney-Client Privilege in the Corporate Arena, 24 Bus. LAw. 901, 907 (1969); Heininger, The Attorney-Client Privilege as it Relates to Corporations, 53 InL. B.J. 376, 385 (1965); Kobak, The Uneven Application of the Attorney-Client Privilege to Corporations in the Federal Courts, $6 \mathrm{GA}$. L. REv. 339, 368 (1972); Maurer, Privileged Communications and the Corporate Counsel, 28 ALA. L. REv. 352, 375 (1967); Miller, The Corporate Attorney-Client Privilege and the Work Product Doctrine: Protection from Compelled Disclosure in Criminal Investigation of a Corporation, 12 U.S.F. L. REv. 569, 597 (1978); Pye, The Attorney-Corporate Client Privilege, Prac. LAw., Nov. 1969, at 15, 19-21; Schaefer, The Attorney-Client Privilege in the Modern Business Corporation, 20 Bus. LAw. 989, 993 (1965); Article, The Corporate Attorney-Client Privilege in the Federal Courts, 22 CATH. Law. 138, 146-47 (1976); Comment, The Application in the Federal Courts of the Attorney-Client Privilege to the Corporation, 39 Fordham L. Rev. 281, 291 (1970); Comment, Privileged Communications-Inroads on the "Control Group" Test in the Corporate Area, 22 Syracuse L. Rev. 759, 761-62 (1971); Comment, The Privileged Few: The Attorney-Client Privilege as Applied to Corporations, 20 U.C.L.A. L. REv. 288, 300-02 (1972) (proposing an "expanded control-group" test that would protect communications from persons who had the ability, at the time the acts causing corporate liability were committed, to take a substantive role in directing business policy of the corporation); 44 B.U. L. REv. 123, 129-30 (advocating a caseby-case balancing approach); 69 Mrch. L. REv. 360, 372-74 (1970); 57 N.C. L. REv. 306, 320 (1979) (endorsing the Diversified test); 23 VAND. L. REv. 847, 853-54 (1970) (advocating a case-by-case balancing approach).

There are two principal concerns addressed by courts that are pertinent to the "correct" formulation of the corporate attorney-client privilege. First, the Seventh Circuit in Radiant Burners, Inc. v. American Gas Ass'n, 320 F.2d 314 (7th Cir.), cert. denied, 375 U.S. 929 (1963), expressed concern that the corporate attorney-client privilege might be abused by the funneling of business documents through the corporate attorney, $320 \mathrm{~F} .2 \mathrm{~d}$ at 324 . Second, dicta in Hickman v. Taylor, 329 U.S. 495 (1947) distinguished (in the case of a partnership) between "employee-clients" and "employee-witnesses," stating that the privilege should be restricted to the former:

On the premise that the attorney-client privilege is the one involved in this case, petitioner argues that it must be strictly confined to confidential communications made by a client to his attorney. And since the materials here in issue were secured by Fortenbaugh [the attorney] from third persons rather than from his clients . . . the conclusion is reached that these materials are proper subjects for discovery under Rule 
is which corporate employees are "clients" for the purposes of privilege. Courts have adopted two basic tests.

The test applied by a majority of jurisdictions is the controlgroup test formulated by Judge Kirkpatrick in City of Philadelphia v. Westinghouse Electric Corp.:

[I]f the employee .... is in a position to control or even to take a substantial part in a decision about any action which the corporation may take upon the advice of the attorney, or if he is an authorized member of a body or group which has that authority, then, in effect, he is (or personifies) the corporation when he makes his disclosure to the lawyer and the privilege would apply. ${ }^{60}$

The second test is the subject-matter test adopted by the Seventh Circuit in Harper \& Row Publishers, Inc. v. Decker. ${ }^{61}$ The test requires that the communication be made by an employee, that it be made at the direction of his superiors, and that the sub-

26.

Id. at 506 (emphasis added).

so 210 F. Supp. 483, 485 (E.D. Pa. 1962), mandamus and prohibition denied sub nom. General Elec. Co. v. Kirkpatrick, 312 F.2d 742 (3d Cir. 1962), cert. denied, 372 U.S. 943 (1963). The control-group test, on its face, is unresponsive to the concern posed by the $R a$ diant Burners court. There is nothing in Judge Kirkpatrick's test to preclude the privilege's attaching to communications to a corporate attorney that are requests for business rather than legal advice. Nor does Hickman necessarily require that middle and lower echelon employees be excluded from the privilege. Hickman technically can be distinguished because it involved a partnership rather than a corporation. The more critical difference, however, lies in the facts of the case. Hickman was an employee prior to his death. The adversaries in the case were his survivors and his former employers. The four surviving crewmen who where deemed "witnesses" by the Court, 329 U.S. at 508 , stood in a position far more analogous to that of the plaintiff than that of the defendant-employers. Had the Court extended the privilege to protect the statements of the survivors from discovery, it would have been seizing on the employment relationship to realign artificially the interests of the surviving crewmen with that of the employers. Although such a realignment might have been technically acceptable, it would have contradicted the realities of the case. Instead the Court effectively cloaked the four with a neutral status in the litigation. The language of the opinion must be read in the context of the factual situation.

One justification given for the control-group test is that it provides a "bright line" for distinguishing between clients and witnesses. Note, Attorney-Client, Privilege for Corporate Clients: The Control Group Test, supra note 59, at 426-27. In fact, the line is anything but bright. In Garrison v. General Motors Corp., 213 F. Supp. 515 (S.D. Cal. 1963), the court held that a division manager and a chief engineer (who was the division manager's assistant) were within the protected group but that two other employees who had disclosed confidential information at the specific request of the chief engineer were not. The court included the chief engineer only because he acted for the division manager in his absence. The corporation could not possibly have predicted the composition of the "control group" at the time it first consulted an attorney.

61 423 F.2d 487 (7th Cir. 1970), aff'd by an equally divided court, 400 U.S. 348 (1971). 
ject matter of the communication be the performance by the employee of the duties of his employment. ${ }^{62}$ The Eighth Circuit later modified the subject-matter test in Diversified Industries, Inc. $v$. Meredith ${ }^{63}$ to require, in addition, that the lawyer be acting in his capacity as legal advisor when the communication was made and that the communication not be disseminated beyond those who needed to know. ${ }^{84}$ The District Court for the District of Columbia in In re Ampicillin Antitrust Litigation ${ }^{65}$ adopted a test similar to the one employed in Diversified, although the communication was required to be "reasonably believed to be necessary to the decision making process concerning a problem on which legal advice was sought." $" 66$

The control-group test would not protect FCPA self-investigations. Since the primary purpose of such an investigation is to apprise the "control group"-upper-level management-of the specifics concerning corporate irregularities committed by subordinates, an attorney conducting such an investigation hardly

ex Id. at 491-92. The second criterion, that the communication be made at the direction of superiors, manifests an acceptance of the idea that those "in control" can expand the scope of the privilege. This is counter to the holding in Garrison v. General Motors Corp., 213 F. Supp. 515 (S.D. Cal. 1963). The Harper \& Row court did not provide a rationale for its decision.

as 572 F.2d 596, 606 (8th Cir. 1977) (en banc).

of The Diversified modification of the Harper \& Row test reflected problems noted by commentators in the broader formulation. Kobak, supra note 59, at 366-67; Article, supra note 59, at 149-50; Comment, Privileged Communications-Inroads on the "Control Group" Test in the Corporate Area, supra note 59, at 766-67; Comment, The Privileged Few: The Attorney-Client Privilege as Applied to Corporations, supra note 59, at 305-06; 23 VAND. L. REV. 847, 852-53 (1970). The Eighth Circuit incorporated limitations suggested by Judge Weinstein. See 2 J. WeINSTEIN, WeInstein's Evidencz \& 403(b) [04] (1975).

os 81 F.R.D. 377 (D.D.C. 1978).

co Id. at 385 (emphasis in original). The broader subject-matter test, as modified by the Eighth Circuit in Diversified and the District Court for the District of Columbia in In re Ampicillin, meets the requirements of both the Radiant Burners concern (the funneling of business documents), and the Hickman dicta (a distinction between employee-clients and employee-witnesses). The requirement that the communication relate to the subject for which legal advice was sought precludes the protection of nonlegal documents. All three courts limited the privilege to communications relating to the employee's duties of employment. This provides a sound basis for distinguishing between employee-clients and employee-witnesses, if the requirement is strictly applied. The court in In re Grand Jury Subpoena, 81 F.R.D. 691 (S.D.N.Y. 1979), rejected the subject-matter test on the grounds that it did not meet the Hickman dicta. "The crewmen in Hickman observed an incident which, while it was apparently of an unusual nature, may generally be said to be within the potential scope of their work." Id. at 694. There is no reason, however, to conclude that the subject-matter test reaches the areas "potentially" within an employee's duties of observation. It is more appropriately limited to what the employee actually did. If this limitation is recognized, the subject-matter test is consistent with the requirements of Hickman. 
could do a thorough job if he confined himself to interviews with upper-level management itself.

The subject-matter test, ${ }^{67}$ on the other hand, would protect such investigations as long as required disclosure to the SEC is not deemed a waiver. $^{88}$ An FCPA self-investigation often is essential for the corporation to comply with the statute; it is not a situation in which the corporation is trying to shield business documents by funneling them through an attorney. ${ }^{69}$ The lawyer conducting such an investigation will need to gather information from all employees whose actions might relate to corporate liability. Because the FCPA makes the corporate entity directly responsible for the actions of such employees, they should be considered "clients" for purposes of the privilege.

The subject-matter test therefore is essential if FCPA selfinvestigations are to be protected by means of the attorney-client privilege. If courts determine that the subject-matter test leads to abuse in situations unlike the FCPA self-investigation and therefore reject it as the generally applicable standard, they nevertheless must fashion a privilege to meet the overriding policy demands of the FCPA. The self-evaluative privilege is the remaining alternative.

\section{B. The Self-Evaluative Privilege}

In Bredice v. Doctors Hospital, Inc. ${ }^{70}$ the seminal case recognizing this privilege, the court held that a monthly review report prepared by the defendant hospital's medical staff was not discoverable in a medical malpractice case. The court distinguished selfevaluations conducted on a routine basis from those prepared in response to a particular crisis or allegation of wrongdoing, noting that the "routine" deliberations were conducted with the expectation of confidentiality, and expessing the fear that such activities would cease if discovery were allowed absent a showing of exceptional necessity. ${ }^{71}$

The Bredice distinction between a routine review and a crisisoriented evaluation led to discovery in two subsequent hospital

\footnotetext{
67 See text and notes at notes 61-66 supra.

se See text and notes at notes 16-34 supra.

60 See note 60 supra.

70 50 F.R.D. 249 (D.D.C. 1970), aff'd, 479 F.2d 920 (D.C. Cir. 1973).

71 Id. at 250.
} 
cases. In Gillman v. United States, ${ }^{72}$ the District Court for the Southern District of New York ordered discovery of factual data concerning a patient suicide but protected statements about hospital procedure. A Colorado district court ${ }^{73}$ relied on Gillman in ordering production of an "Infection Control Report." The hospital's Infection Control Committee was called into action only when an infection problem arose; hence, the court reasoned, it was not susceptible to inhibition. The court ordered disclosure of the entire report, which contained opinions and evaluations as well as factual data.

On the other hand, an application of the Bredice reasoning by the District Court for the Northern District of Georgia precluded discovery of a report prepared by an employer's self-evaluation team concerning the company's compliance with federal employment discrimination laws. ${ }^{74}$ Although the report arguably was prepared in anticipation of litigation, the court offered the public-policy rationale for protecting the actual report which contained evaluative material. Nevertheless, it ordered that any factual or statistical material relied on in the study be subject to discovery.

In Webb $v$. Westinghouse Electric Corp., ${ }^{75}$ the Eastern District of Pennsylvania court provided the most thorough analysis of the public-policy rationale for the self-evaluative privilege. The court drew a distinction between objective and subjective material $^{78}$ and also noted that the employment discrimination laws relied on plaintiffs' suits (which require discovery of relevant information in order to succeed) as well as on voluntary compliance to eradicate discrimination. In reviewing the case law, the court formulated three "guideposts" for protecting such self-analysis: (1) materials protected generally had to have been prepared for mandatory government reports; (2) only subjective, evaluative materials were protected; (3) discovery was denied only when the policy favoring exclusion clearly outweighed the plaintiff's need. ${ }^{27}$ Applying this standard, the court ordered production of the "selfcritical analysis" at issue.

Under the standards that emerge from the foregoing cases, the corporation conducting an internal investigation pursuant to the

3253 F.R.D. 316 (S.D.N.Y. 1971).

73 Davidson v. Light, 79 F.R.D. 137 (D. Colo. 1978),

74 Banks v. Lockheed-Georgia Co., 53 F.R.D. 283 (N.D. Ga. 1971).

${ }^{76} 81$ F.R.D. 431 (E.D. Pa. 1978).

78 Id. at 433-34.

77 Id. at 434. 
FCPA could not safely rely on the self-evaluative privilege to shield its product from discovery. If the investigation were a routine one, conducted to ensure compliance with section 102 requirements, it might be deemed privileged. If the $W e b b$ reasoning were followed, however, the privilege might not extend to statements made by employees ${ }^{78}$ Further, privileged status would be available only if the court decided, on the particular facts, that the corporation's need to maintain confidentiality outweighed the plaintiff's need for discovery. ${ }^{79}$ If the analogous reasoning of the medical malpractice cases, distinguishing between general reviews and crisis reports, were adopted, the investigation might not be protected if it were prompted by suspicion of an illegal payment. Within the selfpolicing framework of the FCPA, however, an investigation should be especially encouraged when corporate management suspects that a possibly illegal payment has been made.

As it is currently applied, the self-evaluative privilege does not give corporations the assurance they require, at the time they undertake a self-investigation, that its results will remain confidential. Because the privilege is the result of a direct balancing between the need for confidentiality and the benefits of disclosure, however, courts are free to construe it more broadly in FCPA cases. ${ }^{80}$

\section{ConClusion}

The accounting and record-keeping provisions and the criminal sanctions of the FCPA combine to place an affirmative duty of self-policing on subject corporations. This mode of deterrence was chosen by Congress instead of a model relying on full corporate disclosure. If the legislative intent is to be furthered, self-policing must be encouraged. This in turn requires that corporate selfinvestigations pursuant to the FCPA be privileged.

7 See the second requirement of the Webb court, text at note 77 supra.

70 See the third requirement of the Webb court, text at note 77 supra.

so The Court of Appeals for the District of Columbia Circuit recently affirmed a district court opinion holding that the self-evaluative privilege did not protect documents sought by the FTC from discovery. FTC v. TRW, Inc., No. 79-2100 (D.C. Cir. June 3, 1980). The court explicitly limited its holding to a discovery request by a governmental agency, noting the "strong public interest in having administrative investigations proceed expeditiously and without impediment," id. at 7, and the fact that Congress had accorded the FTC broad investigatory and subpoena powers, id. at 8.

In private litigation, however, the public interest in disclosure is significantly reduced. Courts, in their discretion, can apply the self-evaluative privilege even if the information in question was previously held discoverable in an administrative proceeding. 
In their current applications, neither the attorney-client privilege nor the self-evaluative privilege provides the certain shield from discovery that is essential to the effectuation of congressional policy. The courts must provide a solution. Strong arguments have been made by commentators ${ }^{81}$ that the broad subject-matter test of corporate privilege should be the general standard. It is clearly the more appropriate in the FCPA context. If courts reject this broad formulation because of possible abuse in other contexts, however, at least they should be willing to expand the self-evaluative privilege to the extent necessary to protect FCPA selfinvestigations.

Jean D. Reed

s1 See text and notes at notes 59-66 supra. 